\title{
Pseudomonas aeruginosa alkaline protease exhibits a high renaturation capability
}

\author{
Mariola Andrejko1 ${ }^{\square}$, Anna Siemińska-Kuczer ${ }^{1}$, Monika Janczarek², Ewa Janik², \\ Mirosława Bednarczyk³, Mariusz Gagoś3 and Małgorzata Cytryńska1 \\ 'Department of Immunobiology, 2Department of Genetics and Microbiology, ${ }^{3}$ Department of Cell Biology, Faculty of Biology and Biotechnol- \\ ogy, Maria Curie-Skłodowska University, Lublin, Poland
}

Thermally induced unfolding and renaturation capability of alkaline proteases (AP) of three Pseudomonas aeruginosa strains, i.e. ATCC 27853 and two clinical isolates, were examined. Sequence analyses demonstrated a high level of aprA genes identity (99.24-99.8\%) in these bacterial strains. The proteases retained $45-60 \%$ and $15 \%$ of their activity after pre-treatment at $60^{\circ} \mathrm{C}$ and $80^{\circ} \mathrm{C}$, respectively, whereas pre-incubation at $90-95^{\circ} \mathrm{C}$ resulted in a higher level of activity than at $80^{\circ} \mathrm{C}$. Zymography analyses and immunoblotting with AP antiserum suggested a high thermostability and renaturation capability of the studied enzymes in comparison to another $P$. aeruginosa protease, elastase B. An intrinsic capability of renaturation of $P$. aeruginosa AP was confirmed by fluorescence spectra of the native, thermally denatured, and renatured enzyme. The value of the fluorescence intensity of the denatured and subsequently cooled enzyme recovered to about $80 \%$ of the value of the native protein fluorescence intensity. Moreover, pre-incubation of the enzyme at $60^{\circ} \mathrm{C}$ and $90^{\circ} \mathrm{C}$ exerted only a slight effect on the intensity of absorbance and the shape of the amide I band, as demonstrated by Fourier transform infrared (FTIR) spectroscopy performed after subsequent cooling of the pre-treated enzyme. The results indicated a high renaturation capability of the $P$. aeruginosa AP proteins.

Key words: Pseudomonas aeruginosa, alkaline protease, zymography, renaturation, steady-state fluorescence spectroscopy, Fourier transform infrared spectroscopy

Received: 19 November, 2018; revised: 22 January, 2019; accepted: 20 February, 2019; available on-line: 04 March, 2019

$\square$ e-mail: mariola.andrejko@poczta.umcs.lublin.pl

Abbreviations: $\mathrm{AP}$, alkaline protease; $\mathrm{BCIP}$, 5-bromo-4-chloro-3-indolyl-phosphate; DEAE-cellulose, diethylaminoethyl-cellulose; FTIR, Fourier transform infrared; NBT, nitro blue tetrazolium; PCR, polymerase chain reaction; PVDF, polyvinylidene difluoride; SDS-PAGE, sodium dodecyl sulfate polyacrylamide gel electrophoresis; IEF/ SDS-PAGE, two-dimensional gel electrophoresis

\section{INTRODUCTION}

The Pseudomonas aeruginosa alkaline protease (EC 3.4.24.40) named aeruginolysin is a zinc-dependent metalloprotease. It is a member of the serralysin family and belongs to the metzincin superfamily of metalloendopeptidases (Rawlings et al., 2010). Aeruginolysin is homologous to $50-\mathrm{kDa}$ metalloproteinases secreted by Serratia marcescens and Dickeya dadantii. An analysis of $P$. aeruginosa aeruginolysin, S. marcescens metalloprotease, and protease $\mathrm{C}$ (PrtC), i.e. one of the four serralysins secreted by $D$. dadantii, had shown that these proteins consist of an N-terminal catalytic domain of about 230 amino acid residues and a $\mathrm{C}$-terminal calcium binding domain of approximately 240 amino acid residues (Okuda et al., 1990; Guzzo et al., 1991; Miyatake et al., 1995). The catalytic domain contains an extended zinc-binding motif HEXXHXUGUXH ( $\mathrm{X}$ and $\mathrm{U}$ indicate an arbitrary and a bulky hydrophobic amino acid, respectively) and a conserved methionine located in a turn near the base of the metal binding pocket. The structural domain that folds into a $\beta$-roll stabilized with calcium ions contains a repetitive glycine-rich nanopeptide, characteristic for repeat-in-toxin (RTX) proteins, and a secretion signal located within the last 70 residues (Baumann et al., 1993; Feltzer et al., 2000; Zhang et al., 2012). The genetic region for the synthesis and secretion of $P$. aeruginosa alkaline protease (AP) contains five open reading frames: $\operatorname{apr} A$ which is a structural gene of the protease, aprI which encodes a protease inhibitor, and aprD, aprE, and aprF genes, whose protein products are involved in secretion of the protease and constitute the Type 1 secretion system (T1SS) in P. aeruginosa (Duong et al., 1992; Duong et al., 1996; Hoge et al., 2010).

Being one of the $P$. aeruginosa virulence factors, alkaline protease is produced during keratitis, otitis media, cystic fibrosis, and bacteraemia (Caballero et al., 2001; Leidal et al., 2003; Guyot et al., 2010; Butterworth et al., 2012) and it is implicated in hydrolysis of many biologically important proteins, including cytokines (Parmely et al., 1990), complement factors (Hong \& Ghebrehiwet, 1992), matrix metalloproteinases (Twining et al., 1993), $\gamma$-interferon and tumor necrosis factor- $\alpha$ (Horvat \& Parmely, 1988; Parmely et al., 1990).

Our previous report demonstrated that three $P$. aeruginosa strains, i.e. a reference strain ATCC 27853 and two human clinical isolates PA C124/9 and PA 02/18, displayed different profiles of secreted proteases depending on the strain and on the medium used for bacterial culture. We had confirmed presence of the las $B$ gene encoding elastase $\mathrm{B}$ and the aprA gene coding for alkaline protease in the genomes of the three $P$. aeruginosa strains analysed. Interestingly, the AP was produced mainly during bacterial growth in minimal M9 medium (Andrejko et al., 2013). Our preliminary experiments revealed a surprising renaturation capability of the AP secreted by $P$. aeruginosa ATCC 27853. Although $P$. aeruginosa alkaline protease has been described (Okuda et al., 1990; Guzzo et al., 1991; Baumann et al., 1993; Miyatake et al., 1995; Bayoudh et al., 2000; Rahman et al., 2006; Patil \& Chaudhari, 2009; Hoge et al., 2010), such a capability has not been reported. To elucidate this issue further and to test if such a feature is characteristic for AP produced by this particular ATCC 27853 strain or whether it is shared 
by alkaline proteases of other $P$. aeruginosa strains, in this paper we studied the thermally induced unfolding and renaturation capability of alkaline proteases of the three $P$. aeruginosa strains, in parallel with comparative sequence analysis of the aprA genes and AP proteins of these bacteria. Given that alkaline protease is considered as one of $P$. aeruginosa virulence factors implicated in many diseases, our results on AP unfolding and renaturation provide an additional insight into $P$. aeruginosa pathogenicity.

\section{MATERIALS AND METHODS}

Bacterial strains and culture conditions. A pyocyanin-producing Pseudomonas aeruginosa strain ATCC 27853 (ATCC) and two human clinical strains PA C124/9 (PA9) and PA 02/18 (PA18) were used in the study. The bacteria were grown overnight at $37^{\circ} \mathrm{C}$ in $\mathrm{M} 9$ minimal medium supplemented with monosodium glutamate $(0.13 \mathrm{M})$, glycerol $(0.1 \mathrm{M})$, and $\mathrm{CaCl} 2(0.01 \mathrm{M})$ on a rotary shaker $(120 \mathrm{rpm})$. For some experiments, the bacteria were cultured in Lysogeny Broth (LB medium, Sigma-Aldrich) as described in our previous report (Andrejko et al., 2013).

DNA methods and sequence analysis. Standard techniques were used for genomic DNA isolation, agarose gel electrophoresis, PCR, and sequencing (Sambrook et al., 1989). PCR amplifications of $1.5-\mathrm{kb}$ long fragments containing the whole alkaline protease gene from P. aeruginosa PA C124/9, PA 02/18, and ATCC 27853 strains were performed using primers aprA-F (forward, 5'-CCTGATCKGGCCGATAACTGCAA'T-3') and aprA-R (reverse, 5'-GGAAGACASCTATCAAT'TCGAACAG-3'), and reaction conditions described earlier (Andrejko et al., 2013). The PCR products obtained were purified on columns (A\&A Biotechnology) and then sequenced using a BigDye terminator cycle sequencing kit (Applied Biosystems) and an ABI Prism 310 sequencer. The sequences generated in this study for the apr $A$ gene of the P. aeruginosa PA C124/9, PA 02/18, and ATCC 27853 strains were deposited in NCBI GenBank under accession numbers: JX853448, JX853449, and JX853450, respectively. An analysis of the sequences at both, the nucleotide and amino acid level, was carried out using the FASTA and BLAST programs available at the European Bioinformatics Institute (Hinxton, UK) and the National Centre for Biotechnology Information (Bethes$\mathrm{da}, \mathrm{MD}, \mathrm{USA})$. Alignment of the amino acid sequences of AP proteins of the $P$. aeruginosa strains and homologous proteases was done by using the Clustal Omega program (http://www.ebi.ac.uk/Tools/services/) (Sievers et al., 2011).

Alkaline protease purification. Bacteria were cultivated in M9 medium under aerobic conditions at $37^{\circ} \mathrm{C}$ for $24 \mathrm{~h}$ with rotational shaking $(120 \mathrm{rpm})$. Then, the bacterial cultures were centrifuged at $8000 \times \mathrm{g}$ for $20 \mathrm{~min}$ at $4^{\circ} \mathrm{C}$ to pellet the cells. The post-culture fluids were filtered through a $0.3 \mu \mathrm{m}$-pore-size filter (Millipore) to remove any remaining bacteria. Proteins secreted into the growth medium were precipitated from the filtrates with ammonium sulphate $\left(90 \%\right.$ saturation) at $4{ }^{\circ} \mathrm{C}$ overnight. The precipitates were collected by centrifugation at $8000 \times g$ for $20 \mathrm{~min}$ at $4^{\circ} \mathrm{C}$, dissolved in $20 \mathrm{mM}$ Tris$\mathrm{HCl} \mathrm{pH}$ 8.0, and dialysed overnight against the same buffer. The dialysed solutions were fractionated using anion-exchange chromatography on a DEAE-cellulose column (DE 52, Whatman) equilibrated with $20 \mathrm{mM}$ Tris- $\mathrm{HCl} \mathrm{pH}$ 8.0. Proteins bound to the column were eluted with a linear gradient of $0-0.7 \mathrm{M} \mathrm{NaCl}$ in the same buffer. Fractions with proteolytic activity, eluted at $0.15-0.22 \mathrm{M} \mathrm{NaCl}$, were pooled, concentrated with polyethylene glycol 20000 (PEG 20000), dialysed overnight against $20 \mathrm{mM}$ Tris- $\mathrm{HCl} \mathrm{pH} 8.0$, lyophilized, and the final preparations were stored at $-20^{\circ} \mathrm{C}$. The protein concentration was estimated using the Bradford method and bovine serum albumin (BSA) as a standard (Bradford, 1976).

Proteolytic activity assay. The alkaline protease activity was measured using a modified method described by Howe and Iglewski (Howe \& Iglewski, 1984). Samples containing $5 \mathrm{mg}$ of the Hide powder azure (HPA, Sigma-Aldrich) dissolved in a buffer $(0.4 \mathrm{ml})$ consisting of $20 \mathrm{mM}$ Tris- $\mathrm{HCl} \mathrm{pH} 8.0$, and $1 \mathrm{mM} \mathrm{CaCl}_{2}$, were mixed with $0.1 \mathrm{ml}$ of the enzyme fraction. The reaction mixtures were incubated at $37^{\circ} \mathrm{C}$ for $60 \mathrm{~min}$ with constant rotation. An undissolved substrate was removed by centrifugation at $4000 \times g$ for $5 \mathrm{~min}$ and the absorbance of the supernatants was determined at $595 \mathrm{~nm}$.

Effect of temperature pre-treatment on alkaline protease activity. The enzyme solutions were pre-incubated for $30 \mathrm{~min}$ at different temperatures in a range of $40-95^{\circ} \mathrm{C}$. To avoid a potential calcium-induced folding and stabilization of the AP proteins, the pre-treatment was carried out in the absence of $\mathrm{Ca}^{2+}$ ions (Zhang et al., 2012). After rapid cooling of the samples in an ice bath, the enzymatic activity was measured under standard assay conditions described above. The relative activities were expressed as a percentage $(\%)$ of the maximum activity determined for each alkaline protease pre-incubated at $40^{\circ} \mathrm{C}$.

Steady-state fluorescence spectroscopy. Fluorescence emission spectra were measured using an F-7000 spectrofluorometer (Hitachi) at $23^{\circ} \mathrm{C}$. The excitation wavelength was set at $280 \mathrm{~nm}$. The excitation and emission slits were $5 \mathrm{~nm}$. The spectra were measured in samples with the same protein concentration. The protein samples were heated for $30 \mathrm{~min}$ at $60^{\circ} \mathrm{C}$ or $90^{\circ} \mathrm{C}$. Next, the samples were cooled for $30 \mathrm{~min}$ at $4^{\circ} \mathrm{C}$. The spectra were analyzed using Grams/AI 9.1 software.

Fourier transform infrared spectroscopy. All measurements were carried out on a Bruker Vertex 70 spectrometer equipped with a liquid $\mathrm{N}_{2}$-refrigerated MCT detector. All spectra were recorded by attenuated total reflection (ATR) at room temperature $\left(22^{\circ} \mathrm{C}\right) \cdot 20-\mu \mathrm{l}$ samples with native protein or samples heated at $60^{\circ} \mathrm{C}$ and $90^{\circ} \mathrm{C}$ for $30 \mathrm{~min}$ and then cooled for $30 \mathrm{~min}$ at $4^{\circ} \mathrm{C}$ were deposited on the 20 -reflection ZnSe crystal at the angle of incidence of $45^{\circ}$. The samples were quickly evaporated in an $\mathrm{N}_{2}$ flux to obtain a homogenous film. The spectrometer was flushed with dry nitrogen gas for at least $30 \mathrm{~min}$ before the spectra were recorded. The FTIR measurements were recorded between 4000 and $800 \mathrm{~cm}^{-1}$. Each spectrum was obtained by averaging 32 scans recorded at a resolution of $2 \mathrm{~cm}^{-1}$. Prior to data analysis, the spectra were baseline-corrected and normalised using the vector normalisation method. The ATR-FTIR spectra were cut to include an amide I band (wavelengths between 1600 and $1700 \mathrm{~cm}^{-1}$ ). The procedure was performed using the OPUS version 7.5 software. OPUS software was used to convert the FTIR absorbance spectra into second derivatives.

Polyacrylamide gel electrophoresis. Protein samples were separated by SDS-PAGE in 10\% polyacrylamide gels under reducing or non-reducing conditions according to Laemmli (Laemmli, 1970). In some experiments, native-PAGE was used. For this purpose, polyacrylamide gels and an electrode buffer did not contain SDS, while the samples were prepared by addition of saccha- 
rose and bromophenol blue to the final concentrations of $20 \%$ and $0.05 \%$, respectively. Two-dimensional gel electrophoresis (IEF/SDS-PAGE) of the proteins was performed using a Protean System (BioRad) according to the manufacturer's instructions. ReadyStripTM IPG Strips $\mathrm{pH}$ 3-10 were used for the first dimension (Andrejko \& Mizerska-Dudka, 2012).

Zymography analysis. Gelatine zymography was conducted following the procedures described by Caballero and others (Caballero et al., 2001). Samples of enzyme solutions ( $1 \mu \mathrm{g}$ protein), non-treated or pre-treated at different temperatures, were electrophoresed under non-reducing conditions using $10 \%$ polyacrylamide gels with $0.1 \%$ gelatine at $4{ }^{\circ} \mathrm{C}$. The purified enzymes were also analysed by zymography after IEF/SDS-PAGE. In this case, the gels used for separation in the second dimension contained $0.1 \%$ gelatine. After electrophoresis, the gels were soaked twice for $30 \mathrm{~min}$ in $2.5 \%$ Triton X-100 for SDS removal and incubated at $37^{\circ} \mathrm{C}$ for $24 \mathrm{~h}$ in a gelatine gel substrate buffer $(50 \mathrm{mM}$ Tris- $\mathrm{HCl} \mathrm{pH}$ 8.0, $10 \mathrm{mM} \mathrm{CaCl}, 1 \mu \mathrm{M} \mathrm{ZnCl}, 150 \mathrm{mM} \mathrm{NaCl}$. The gels were stained for $60 \mathrm{~min}$ in $0.2 \%$ amido black and then destained in 10\% acetic acid.

Immunoblotting. After electrophoretic separation (SDS-PAGE, native-PAGE, or IEF/SDS-PAGE), the proteins were electrotransferred onto PVDF membranes (Millipore) for $90 \mathrm{~min}$ at $350 \mathrm{~mA}$. The membranes were blocked with $5 \%$ non-fat milk in Tris-buffered saline (TBS; 10 mM Tris- $\mathrm{HCl} \mathrm{pH} 7.5,0.9 \% \mathrm{NaCl}$ ). For identification of the alkaline protease, the membranes were probed with a polyclonal rabbit AP antiserum (1:1000) (kindly provided by Dr. R. Voulhoux). Alkaline phosphatase-conjugated goat anti-rabbit IgGs (1:30000) (Sigma-Aldrich) were used as secondary antibodies and immunoreactive bands were visualized by incubation with p-nitro blue tetrazolium chloride (NBT) and 5-bromo-4chloro-3-indolyl phosphate (BCIP) (Blake et al., 1984).

\section{RESULTS}

\section{Purification and identification of alkaline proteases secreted by the $P$. aeruginosa strains}

The alkaline proteases (AP) of the three $P$. aeruginosa strains were purified from the 24-h post-culture fluids by ammonium sulphate precipitation and ion-exchange chromatography on DEAE-cellulose. The results of zymography performed under non-reducing SDS-PAGE conditions revealed the presence of one $52 \mathrm{kDa}$ band of proteolytic activity irrespective of the strain (Fig. 1A). Immunoblotting with the polyclonal rabbit AP antiserum clearly confirmed that the alkaline protease was responsible for the proteolytic activity detected in all of the final preparations (Fig. 1B). In addition, a single spot of proteolytic activity was detected when AP protein produced by the PA18 strain was analyzed by zymography after IEF/SDS-PAGE (Fig. 1C). It clearly corresponded to that of approx. pI 4.5 recognized by the anti-alkaline protease antibodies (Fig. 1D). The theoretical isoelectric point of this protein was calculated as pI 4.28 on the basis of amino acid sequence presented in Fig. 7 .

\section{Effect of temperature pre-treatment on the activity of alkaline proteases}

The activity of the studied enzymes was measured after 30-min pre-incubation at different temperatures ranging from $40^{\circ} \mathrm{C}$ to $95^{\circ} \mathrm{C}$ and subsequent cooling at the ice
(A)

(B)

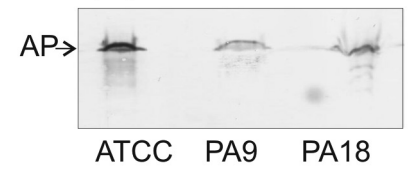

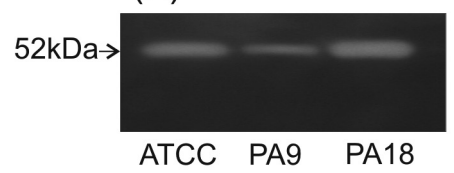

(C)

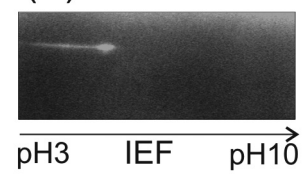

(D)

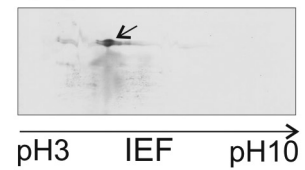

Figure 1. Identification of alkaline proteases of three $P$. aeruginosa strains in the final preparations obtained by ion-exchange chromatography on DEAE-cellulose.

(A, C) Alkaline protease zymography analysis and (B, D) detection by specific antibodies. The proteins $(1 \mu \mathrm{g})$ were resolved by non-reducing SDS-PAGE in gelatine gels $(\mathbf{A})$ and in standard gels (B) for zymography and alkaline protease detection, respectively. For the 2D electrophoresis $(\mathbf{C}, \mathbf{D})$, the alkaline protease produced by $P$. aeruginosa PA18 ( $2 \mu \mathrm{g}$ of protein) was resolved in the first dimension by IEF $\mathrm{pH} 3-10$. In the second dimension, the protein was separated by SDS-PAGE under non-reducing conditions in a gel containing $0.1 \%$ gelatine $(\mathbf{C})$ and by standard SDS-PAGE (D) for zymography and alkaline protease detection, respectively. The gelatine gels were washed and stained as described in Materials and Methods. Alkaline protease was detected after transferring proteins onto PVDF membranes and probing with anti- $P$. aeruginosa alkaline protease antibodies (B and $D)$. The results shown in $(\mathbf{A}, \mathbf{B})$ and $(\mathbf{C}, \mathbf{D})$ are typical representatives of at least five and three independent experiments, respectively. The positions of alkaline protease (AP) are marked by arrows. ATCC - reference strain, PA9 and PA18 - clinical isolates.

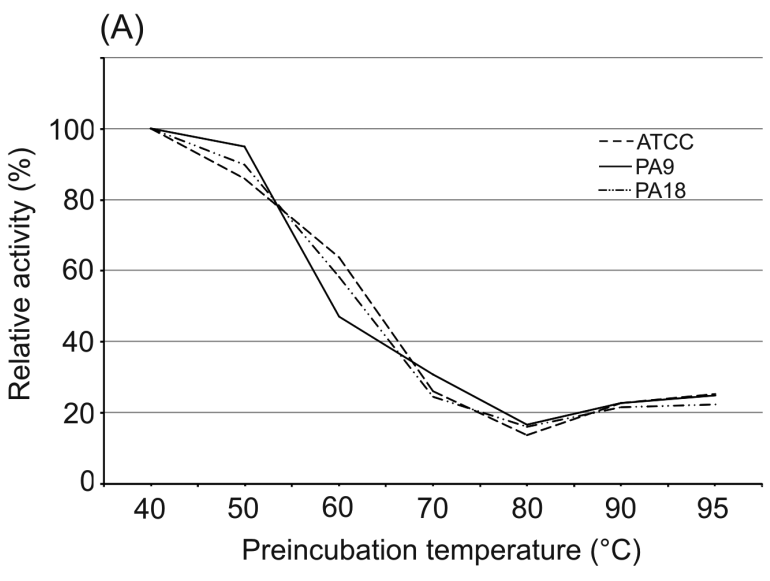

(B)

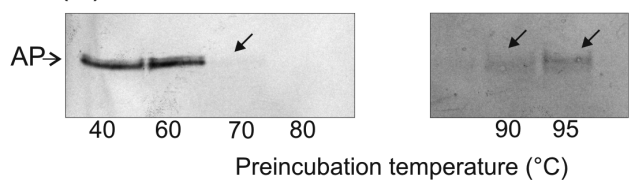

Figure 2. Effect of temperature on the activity of alkaline proteases.

The enzymes were pre-incubated at different temperatures in the range of $40-95^{\circ} \mathrm{C}$ for $30 \mathrm{~min}$. (A) The remaining activity was determined with the Hide powder azure as a substrate under standard assay conditions (see Materials and Methods). The activity was expressed as a percentage of the value at $40^{\circ} \mathrm{C}$, which was taken as $100 \%$. (B) For alkaline protease detection, the samples $(1 \mu \mathrm{g}$ of protein) were resolved by native PAGE, transferred onto PVDF membranes, and probed with anti-P. aeruginosa alkaline protease antibodies. The immunoblottings shown are typical representatives of at least three independent experiments. ATCC - reference strain, PA9 and PA18 - clinical isolates. 
Table 1. Effect of temperature on the activity of alkaline proteases

\begin{tabular}{|c|c|c|c|}
\hline Temperature $\left[{ }^{\circ} \mathrm{C}\right]$ & ATCC [\%] & PA9 [\%] & PA18 [\%] \\
\hline 50 & $90.27 \pm 3.69$ & $90.17 \pm 3.92$ & $90.40 \pm 3.65$ \\
\hline 60 & $56.37 \pm 6.99$ & $56.20 \pm 7.01$ & $56.07 \pm 6.62$ \\
\hline 70 & $27.10 \pm 2.69$ & $26.57 \pm 2.31$ & $15.43 \pm 1.25$ \\
\hline 80 & $15.43 \pm 1.25$ & $15.33 \pm 1.30$ & $15.03 \pm 1.24$ \\
\hline 90 & $23.13 \pm 0.66$ & $23.00 \pm 1.88$ & $23.07 \pm 1.43$ \\
\hline 95 & $24.07 \pm 1.37$ & $23.33 \pm 1.48$ & $23.07 \pm 1.15$ \\
\hline
\end{tabular}

Enzymes were pre-incubated at different temperatures in the range of $40-95^{\circ} \mathrm{C}$ for 30 min. The remaining activity was determined with the Hide powder azure as a substrate under standard assay conditions (see Materials and Methods). Activity was expressed as a percentage of the value at $40^{\circ} \mathrm{C}$, which was taken as $100 \%$. ATCC - reference strain, PA9 and PA18 - clinical isolates. The results are presented as \pm S.D. from three independent experiments. Percent of activity at corresponding incubation temperatures were statistically significant $(p<0.05)$, as determined by analysis of variance (ANOVA).

bath. As presented in Fig. 2, the proteases pre-incubated at $40^{\circ} \mathrm{C}$ exhibited the highest activity (Fig. 2A, Table 1). The enzymes pre-treated at $50^{\circ} \mathrm{C}$ and $60^{\circ} \mathrm{C}$ retained $86-$ $95 \%$ and $45-60 \%$ of the activity, respectively, whereas a gradual decrease in the activity level was noticed after pre-incubation at higher temperatures $\left(70-80^{\circ} \mathrm{C}\right)$. However, the proteases still exhibited $15 \%$ of the maximum activity after $30-\mathrm{min}$ pre-incubation at $80^{\circ} \mathrm{C}$ (Fig. 2A). Surprisingly, after pre-treatment at $90^{\circ} \mathrm{C}$ and $95^{\circ} \mathrm{C}$, the proteolytic activity was higher in comparison to the enzymes pre-incubated at $80^{\circ} \mathrm{C}$. The activity level was only slightly lower than the one obtained for the $70^{\circ} \mathrm{C}$ pretreated proteases (Fig. 2A).

In accordance with these results, only a trace signal was recognized by the anti-AP antibodies in the enzyme preparations pre-incubated at temperatures higher than $60^{\circ} \mathrm{C}$ and separated by native-PAGE, in contrast to the clear signal detected in the preparations pre-incubated at lower temperatures (Fig. 2B). Interestingly, the proteases pre-treated at $90^{\circ} \mathrm{C}$ and $95^{\circ} \mathrm{C}$ were better recognized by the antibodies than the $70^{\circ} \mathrm{C}$ and $80^{\circ} \mathrm{C}$ pre-incubated enzymes. However, the loss of the AP protein in preparations exposed to higher temperatures was not responsible for the observed effect, because anti-AP antibodies recognized an equally strong signal in the pre-incubated enzyme preparations separated by SDS-PAGE, regardless of the pre-treatment temperature (Fig. 3A). These results suggested different alterations in the spatial conformation of the enzyme molecules occurring depending on the temperature conditions and finally resulting in gradual loss of activity. Such alterations, by affecting accessibility of different epitopes, may also explain the observed weak binding of the anti-AP antibodies after native-PAGE (Fig. 2B).

Unexpectedly, when the activity of the proteases preincubated for $30 \mathrm{~min}$ at temperatures of $60-95^{\circ} \mathrm{C}$ was assayed by zymography after SDS-PAGE, the evident clear bands of gelatine proteolytic degradation were detected, even after thermal denaturation at the highest temperature used (Fig. 3B). These results suggest that the studied alkaline proteases exhibit a high renaturation capability. After being further subjected to additional denaturing conditions during SDS-PAGE, they regained the native spatial conformation and activity upon appropriate zymography conditions. In contrast, the enzymatic activity of the other extracellular metalloprotease, elastase $\mathrm{B}$, produced by the three $P$. aeruginosa strains used, especially during growth in the LB medium (Andrejko et al., 2013), was not restored when tested under the same conditions after thermal denaturation (Fig. 3C, D), further supporting the high renaturation capability of the studied AP proteins.

\section{Spectroscopic analyses}

To elucidate whether the intrinsic capability of renaturation could be, at least in part, responsible for the effects described above, AP produced by $P$. aeruginosa PA18 was analyzed by steady-state fluorescence spectroscopy and Fourier transform infrared spectroscopy after thermal denaturation at $60^{\circ} \mathrm{C}$ and $90^{\circ} \mathrm{C}$.

Because fluorescence signals are very sensitive to the conformational organization of the macromolecule (Lakowicz, 1999), changes in the molecular organization of the enzyme associated with denaturation and renaturation were examined using steady-state fluorescence spectroscopy (Chanchal et al., 2014; Ghisaidoobe \& Chung, 2014). In order to verify the denaturation of the protease under the high temperature treatment, fluorescence spectra of native protein and protein incubated at $60^{\circ} \mathrm{C}$ for $30 \mathrm{~min}$ were measured. The spectra were detected at $23^{\circ} \mathrm{C}$ and $60^{\circ} \mathrm{C}$, respectively. Measurement of

(A)

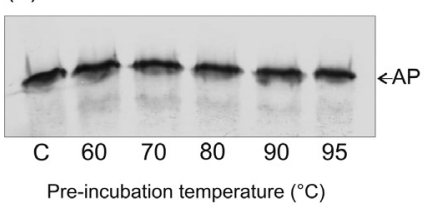

(B)

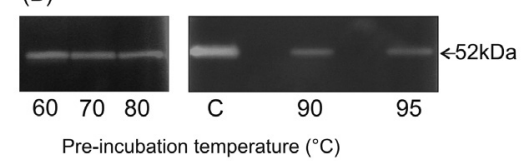

(C)
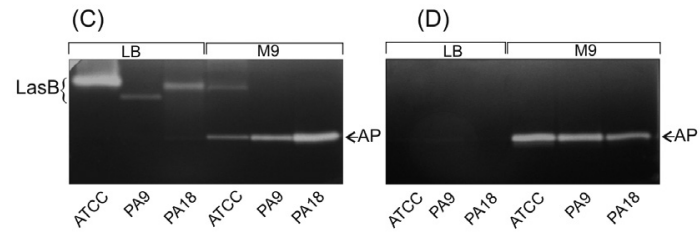

Figure 3. Immunodetection (A) and zymography analysis (B) of thermally pre-treated $P$. aeruginosa PA18 alkaline protease.

The enzyme was pre-incubated at $60-95^{\circ} \mathrm{C}$ for $30 \mathrm{~min}$ and subjected to SDS-PAGE and immunobloting (A) or zymography (B) as described in Materials and Methods. C - control (non-temperature treated) sample. Similar results were obtained for alkaline proteases of two other $P$. aeruginosa strains studied. The renaturation ability of $P$. aeruginosa elastase B was additionally analyzed (C, D). Post-culture fluids (after $24 \mathrm{~h}$ of culture) of $P$. aeruginosa strains grown in the LB and M9 medium were pre-incubated at $60^{\circ} \mathrm{C}$ (C) and $85^{\circ} \mathrm{C}$ (D) for $10 \mathrm{~min}$. The enzyme activities were determined by zymography after non-reducing SDS-PAGE as described in Materials and Methods. The zymograms shown are typical representatives of at least five independent experiments. The positions of alkaline protease (AP) and elastase B (LasB) are marked. ATCC reference strain, PA9 and PA18 - clinical isolates. 


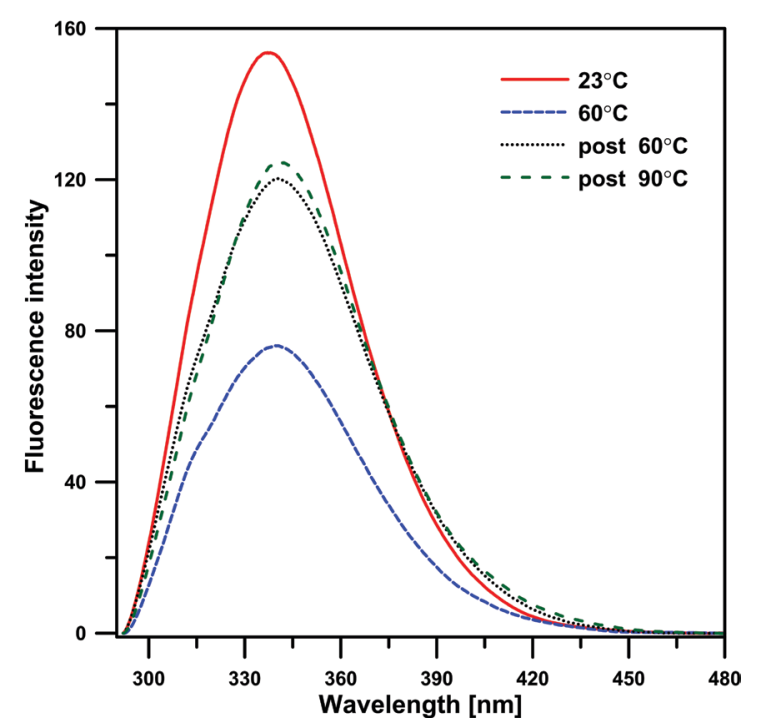

Figure 4. Fluorescence emission spectra of $P$. aeruginosa PA18 alkaline protease.

The enzyme was pre-incubated at $60^{\circ} \mathrm{C}$ and $90^{\circ} \mathrm{C}$ for $30 \mathrm{~min}$ and then cooled for $30 \mathrm{~min}$ at $4^{\circ} \mathrm{C}$. Solid red line - sample before heat treatment $\left(23^{\circ} \mathrm{C}\right)$, dashed blue line - sample heated at $60^{\circ} \mathrm{C}$, dotted black line - sample heated at $60^{\circ} \mathrm{C}$ and cooled for $30 \mathrm{~min}$ at $4^{\circ} \mathrm{C}$ (post $60^{\circ} \mathrm{C}$ ), dashed green line - sample heated at $90^{\circ} \mathrm{C}$ and cooled for $30 \mathrm{~min}$ at $4{ }^{\circ} \mathrm{C}$ (post $90^{\circ} \mathrm{C}$ ). Excitation at $280 \mathrm{~nm}$. More details are provided in the Materials and Methods section.

the fluorescence spectrum at $90^{\circ} \mathrm{C}$ was impossible due to equipment limitations. As presented in Fig. 4, the maximum of the fluorescence emission spectrum of the native protein was centred at $337 \mathrm{~nm}$. Since typical tryptophan fluorescence emission in a water solution at neutral $\mathrm{pH}$ is located at $348 \mathrm{~nm}$, the blue shift of maximum fluorescence emission from the native enzyme indicated that tryptophan residues are buried in a hydrophobic environment within the protein (Lakowicz, 1999; Moller \& Denicola, 2002; Ghisaidoobe \& Chung, 2014). Heat treatment $\left(60^{\circ} \mathrm{C}\right)$ decreased the intrinsic protein fluorescence intensity by approx. 50\% and red-shifted the maximum fluorescence to $340 \mathrm{~nm}$. In order to confirm protein renaturation, the fluorescence emission spectra of the protein samples pre-incubated at $60^{\circ} \mathrm{C}$ or $90^{\circ} \mathrm{C}$ and next cooled for $30-\mathrm{min}$ at $4^{\circ} \mathrm{C}$ were measured (Fig. 4). Surprisingly, the value of fluorescence intensity recovered to about $80 \%$ of the fluorescence intensity of the native protein. This result indicated the recovery of the enzyme molecular conformation after protein cooling, although not completely. Figure 5A shows the fluorescence emission spectra presented in Fig. 4 normalized to get the same area beneath each spectrum. This analysis allowed determination of the relative abundance of different molecular forms of the protein in the samples with its native, denatured, or renatured form. As can be seen from the difference spectrum (Fig. 5B), the heat-induced $\left(60^{\circ} \mathrm{C}\right)$ protein denaturation was associated with a slight bathochromic spectral shift of the main emission band and with appearance of a new spectral form which gave rise to fluorescence emission band centred at $377 \mathrm{~nm}$. This band had even higher intensity in the case of the renatured samples; the highest intensity was detected for the protein pre-treated at $90^{\circ} \mathrm{C}$.

The changes in the secondary structure of the protein are closely correlated with the wavenumber position and the shape of the amide I band (Goormaghtigh et al., 2009; Caine et al., 2012). The infrared spectroscopic analysis of the amide I band revealed that the secondary

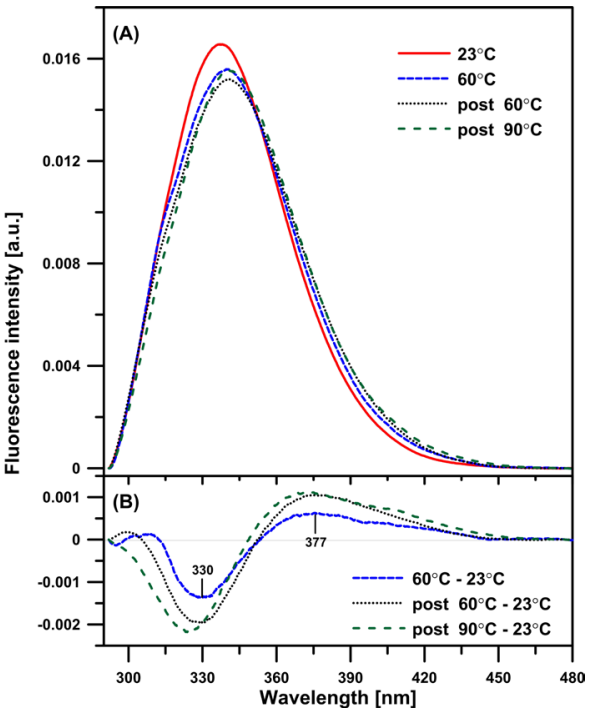

Figure 5. Normalized (A) and differential (B) fluorescence emission spectra of $P$. aeruginosa PA18 alkaline protease.

(A) The spectra were normalized to get the same area beneath each spectrum. Solid red line - sample before heat treatment $\left(23^{\circ} \mathrm{C}\right)$, dashed blue line - sample heated at $60^{\circ} \mathrm{C}$, dotted black line - sample heated at $60^{\circ} \mathrm{C}$ and cooled for $30 \mathrm{~min}$ at $4{ }^{\circ} \mathrm{C}$ (post $60^{\circ} \mathrm{C}$ ), dashed green line - sample heated at $90^{\circ} \mathrm{C}$ and cooled for 30 min at $4{ }^{\circ} \mathrm{C}$ (post $90^{\circ} \mathrm{C}$ ). (B) Differential spectra calculated on the basis of the spectra presented in panel (A). Excitation at 280 $\mathrm{nm}$. More details are provided in the Materials and Methods section.

structure of the $P$. aeruginosa alkaline protease is mainly composed of $\beta$ turns $\left(1615 \mathrm{~cm}^{-1}\right)$ and $\beta$-pleated sheets $\left(1637-1623 \mathrm{~cm}^{-1}\right)$ with a small proportion of $\alpha$-helix $\left(1655 \mathrm{~cm}^{-1}\right)$ and random coil $\left(1637-1645 \mathrm{~cm}^{-1}\right)$ configurations, which is evidenced by the position of the maximum of the amide I band of P. aeruginosa PA 02/18 alkaline protease (Fig. 6A) and is consistent with literature data on the molecular organization of $P$. aeruginosa AP protease (Baumann et al., 1993; Miyatake et al., 1995; Zhang et al., 2012).

The experimental procedure consisting of pre-incubation of the enzyme for $30 \mathrm{~min}$ at $60^{\circ} \mathrm{C}$ and $90^{\circ} \mathrm{C}$ and then cooling, exerted a slight effect on the intensity of absorbance and the shape of the amide I band (Fig. 6AC). Pre-incubation of the alkaline protease at $60^{\circ} \mathrm{C}$ and $90^{\circ} \mathrm{C}$ decreased the intensity of amide I absorbance by $5.2 \%$ and only $4.5 \%$, respectively. The high capability of renaturation by the analyzed enzyme is confirmed by only subtle changes in the shape of the amide I band, as shown in the differential spectra and their secondary derivatives (Fig. 6B, C). Pre-incubation at $60^{\circ} \mathrm{C}$ and $90^{\circ} \mathrm{C}$ caused a slight shift of the band, typical of the $\alpha$-helix $\left(1655 \mathrm{~cm}^{-1}\right)$, towards localization of the $\beta$-sheet band and a decrease in the $\beta$-sheet band intensity $\left(1629 \mathrm{~cm}^{-1}\right)$, which in turn resulted in narrowing of the amide I band. Concomitantly with this decrease, a slight increase of aggregated strands $\left(1600-1620 \mathrm{~cm}^{-1}\right)$ was noticed. Paradoxically, these changes exhibited higher intensity at pre-incubation of the examined enzyme at $60^{\circ} \mathrm{C}$.

\section{Sequence analysis of the aprA gene and AP protein in three $P$. aeruginosa strains}

In order to shed light on possible determinants of the high renaturation ability, the nucleotide sequence analysis of aprA genes followed by analysis of their deduced amino acid sequences was carried out. The presence of aprA genes encoding the alkaline protease in $P$. aeruginosa PA9, 


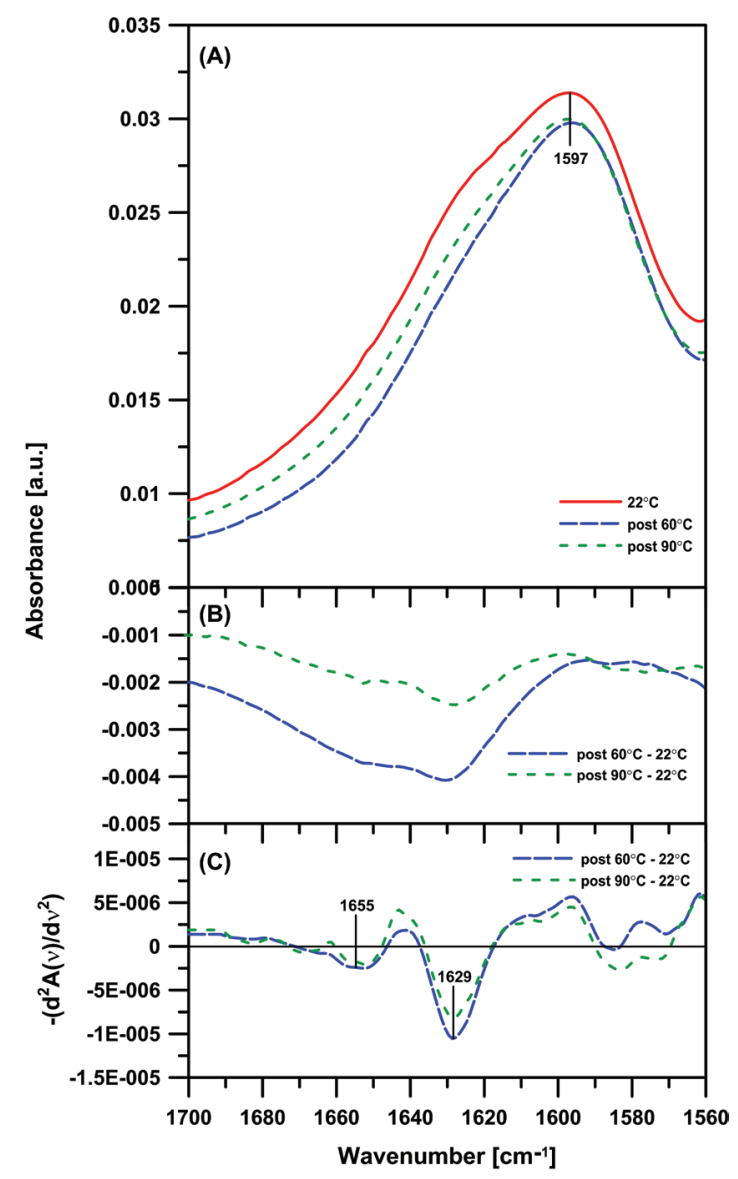

Figure 6. Fourier transform infrared spectroscopy of $P$. aeruginosa PA18 alkaline protease.

(A) FTIR spectra of the thermal processing effects on the amide I region: native protein at $22^{\circ} \mathrm{C}$ (solid red line), sample heated at $60^{\circ} \mathrm{C}$ and cooled for $30 \mathrm{~min}$ at $4{ }^{\circ} \mathrm{C}$ (post $60^{\circ}$ - dashed blue line), sample heated at $90^{\circ} \mathrm{C}$ and cooled for 30 min at $4{ }^{\circ} \mathrm{C}$ (post $90^{\circ} \mathrm{C}-$ dashed green line). (B) Differential spectra of the amide I region obtained by subtracting the spectrum of native protein at $22^{\circ} \mathrm{C}$ from the spectrum of thermal processing at $60^{\circ} \mathrm{C}$ (post $60^{\circ} \mathrm{C}-$ $22^{\circ} \mathrm{C}$ ), the spectrum of native protein at $22^{\circ} \mathrm{C}$ subtracted from the spectrum of thermal processing at $90^{\circ} \mathrm{C}$ (post $90^{\circ} \mathrm{C}-22^{\circ} \mathrm{C}$ ). (C) Second derivative spectra corresponding to (B). More details are provided in the Materials and Methods section.

PA18, and ATCC 27853 strains was confirmed in our previous report (Andrejko et al., 2013). For all of the bacterial strains analysed, $1.5-\mathrm{kb}$ long amplicons encompassing the whole gene for alkaline protease were obtained. The nucleotide sequence analyses of these PCR products revealed that the PA9, PA18, and ATCC 27853 strains have a functional aprA gene in their genomes. The genes for the alkaline protease contain a 1445-bp-long open reading frame, which begins with an ATG codon and terminates with a TGA stop codon, and encodes a 481aa long protein. The aprA genes of these strains show a very high level of nucleotide sequence identity, which is $99.8 \%$ between the PA9 and PA18 strains, $99.5 \%$ between the PA 18 and ATCC 27853 strains, and 99.24\% between the PA9 and ATCC 27853 strains. These genes are also highly homologous to other alkaline metalloprotease genes available in the GenBank database, having from $99 \%$ to $100 \%$ identity to the aprA gene of $P$. aeruginosa strain NCGM2 (accession no. AP012280), 99\% identity to the aprA gene of $P$. aeruginosa strain PAO1 (acc. no. AE004091), and 77\% identity to Pseudomonas fluorescens strain A506 (acc. no. AY298902). These data indicate that genes encoding this type of enzymes are highly conserved in bacterial species. Also, at the amino acid level, the protein products of aprA from the $P$. aeruginosa PA9, PA18, and ATCC 27853 strains are almost identical; only three different amino acids were identified in the whole sequence of these proteins (positions 115, 209, and 437 aa) (Fig. 7). The molecular masses of these enzymes calculated from their amino acid sequences are $50.7 \mathrm{kDa}$. The AP proteins of the PA9, PA18, and ATCC 27853 strains show significant homology to enzymes belonging to alkaline metalloproteases (ZnMc-serralysin-like subfamily) containing the HEXXHXUGUXH motif with three histidine residues responsible for zinc ion coordination. P. aeruginosa AP proteins have an identical HEIGHTLGLSH motif (conserved aa are underlined), which is located in their sequence region spanning from 187 to 197 aa. The N-terminal (1-258 aa) and Cterminal (259-481 aa) regions of these proteins comprise a Zn-binding serralysin-like domain and a peptidase M10 serralysin domain, respectively. The AP proteins of the PA9, PA18, and ATCC 27853 strains show the highest sequence homology to AP of P. aeruginosa PAO1 $(99 \%$ identity, 100\% similarity) (acc. no. NP_249940) and the alkaline metalloproteinase precursor of $P$. aeruginosa PA7 (95\%/98\%) (ABR83878). However, there was a high degree of homology with serralysin of $P$. syringae pv. tabaci ATCC $11528(64 \% / 76 \%)$ (EGH90818), extracellular alkaline metalloprotease AprA of P. fuorescens A506 $(60 \% / 73 \%)$ (AFJ54733), serralysin-like metalloprotease of P. putida (65\%/77\%) (WP_038994098), and serralysin of Serratia marcescens SM6 (54\%/68\%) (P23694). These data confirm that the aprA genes identified in the genomes of the $P$. aeruginosa PA9, PA18, and ATCC 27853 strains encode proteins whose sequences are very similar to each other and highly conserved in the Pseudomonas species. Among these three AP proteins, enzymes from PA9 and PA18 proved to be the most similar but more distantly located in relation to that from strain ATCC 27853.

\section{DISCUSSION}

In the study presented here, alkaline proteases of three $P$. aeruginosa strains were obtained from post-culture fluids after cultivation of bacteria in the synthetic minimal M9 medium. The $52 \mathrm{kDa}$ protein band was recognized by specific anti- $P$. aeruginosa alkaline protease antibodies, confirming production of this protease by all of the $P$. aeruginosa strains studied. The results of sequence analyses and similarity searches provided clear evidence that each of the three proteases can be undoubtedly classified as an $P$. aeruginosa alkaline protease.

The studied proteases retained $45-60 \%$ of their activity after pre-treatment at $60^{\circ} \mathrm{C}$, and $15 \%$ of the activity after $30 \mathrm{~min}$ pre-incubation at $80^{\circ} \mathrm{C}$. Interestingly, pre-incubation at $90-95^{\circ} \mathrm{C}$ resulted in a higher activity level than at $80^{\circ} \mathrm{C}$, suggesting that the treatment at these temperatures induced different alterations in the protein molecular organization. The retention of partial activity after heat treatment and subsequent cooling pointed toward a high renaturation capability of the $P$. aeruginosa alkaline proteases, an attribute that has not been reported earlier. In comparison to some alkaline proteases of other $P$. aeruginosa strains reported in the literature, the studied enzymes were even more thermostable. Bayoudh and others (Bayoudh et al., 2000) reported that the alkaline protease of the MN1 strain retained more than $90 \%$ and $66 \%$ of the initial activity after 15 and $120 \mathrm{~min}$ 


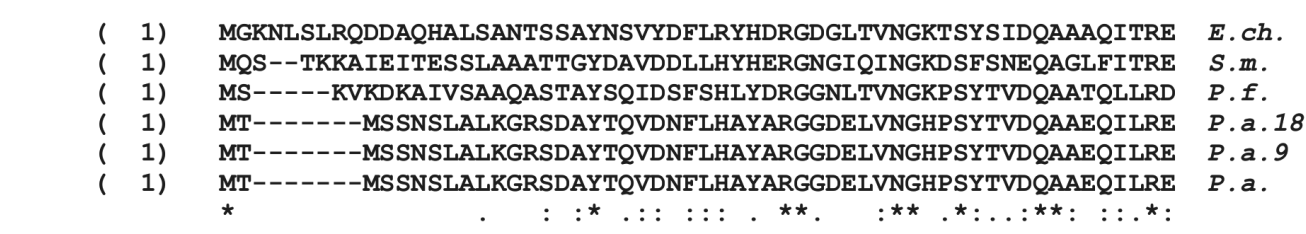

NVSWNGTNVFGKSANLTFKFLOS--VSNQTWNGYKVFGQPVKLTFSFPDYKFSS-------TNVAGDTGLSKFSAEQQQQAKLSLQ GAAYRDFDGNGK-IDLTYTFLTSATQST-------MNKHGISGFSQFNTQQKAQAALAMQ QASWQKAPGDSV-LTLSYSFLTKPNDFFNTPWKYVSDIYSLGKFSAFSAQQQAQAKLSLQ QASWQKAPGDSV-LTLSYSFLTKPNDFFNTPWKYVSDIYSLGKFSAFSAQQQAQAKLSLQ QASWQKAPGDSV-LTLSYSFLTKPNDFFNTPWKYVSDIYSLGKFSAFSAQQQAQAKLSLQ

$$
\begin{aligned}
& \text {... } \\
& \text { * ...* : } \\
& :::^{*} .^{\star} \ldots{ }^{\star}::^{*}:{ }^{\star}
\end{aligned}
$$

SWSDVANLTFTEVTGNKSANITFGNYTRDASGNLDYGTOAYAYYPGNYQ----GAGSSWY SWADVANITFTEVAAGQKANITFGNYSQDRPGHYDYGTQAYAFLPNTIWQGQDLGGQTWY SWADVANVTFTEKASGGDGHMTFGNYSSGODG-----AAAFAYLPGT---GAGYDGTSWY SWADVTNIHFVDAGQGDQGDLTFGNFSSSV-G-----GAAFAFLPDV---PDALKGQSWY SWADVTNIHFVDAGOGDOGDLTFGNFSSSV-G-----GAAFAFLPDV---PDALKGOSWY SWSDVTNIHFVDAGQGDOGDLTFGNFSSSV-G-----GAAFAFLPDV---PDALKGQSWY

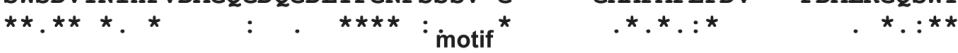
NYNQSN--IRNPGSEEYGRQTFTHEIGHALGLAHPGEYNAGEGDPSYNDAVYAEDSYQFS NVNOSN--VKHPATEDYGROTFIHEI I HAL GLSHPGDYNAGEGNPTYRDVTYAEDTROFS LTNNSYTPNKT PDLNNYGROTLTHEI I HTLGLA HPGDYNAGNGNPTYNDATYGODTRGYS LINSSYSANVNPANGNYGRQTLTHEIGHTLGLSHPGDYNAGEGDPTYADATYAEDTRAYS LINSSYSANVNPANGNYGROTLTHEIGHTLGLSHPGDYNAGEGDPTYADATYAEDTRAYS LINSSYSANVNPANGNYGRQTLTHEIGHTLGLSHPGDYNAGEGDPSYADATYAEDTRAYS

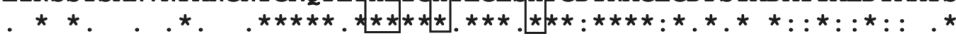
Zn-binding residues

IMSYWGENETGADYN----GHYGGAPMIDDIAAIQRLYGANMTTRTGDSVYGFNSNTDRD LMSYWSETNTGGDNG-----GHYAAAPLIDDIAAIOHLYGANLSTRTGDTVYGFNSNTGRD LMSYWSE SNTNQNFSKGGVEAYASGPLIDDIAAIQKLYGANLSTRATDTTYGFNSNTGRD VMSYWEEQNTGQDFK----GAYSSAPLIDDIAAIQKLYGANLTTRTGDTVYGFNSNTERD VMSYWEEQNTGQDFK----GAYSSAPLIDDIAAIQKLYGANLTTRTGDTVYGFNSNTERD VMSYWEEQNTGQDFK----GAYSSAPLIDDIAAIQKLYGANLTTRTGDTVYGFNSNTERD

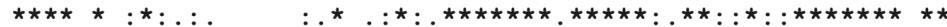

FYTATDSSKALIFSVWDAGGTDTFDFSGYSNNQRINLNEGSFSDVGGLKGNVSIAHGVTI FLSTTSNSOKVIFAAWDAGGNDTFDFSGYTANORINLNEKSFSDVGGLKGNVSIAAGVT I FLSASSNADKLVF SVWDGGGNDTLDFSGFTQNQKINLTATSFSDVGGLVGNVSIAKGVTI FYSATSSSSKLVFSVWDAGGNDTLDFSGFSONQKINLNEKALSDVGGLKGNVSIAAGVTV FYSATSSSSKLVFSVWDAGGNDTLDFSGFSQNQKINLNEKALSDVGGLKGNVSIAAGVTV FYSATSSSSKLVFSVWDAGGNDTLDFSGFSQNQKINLNEKALSDVGGLKGNVSIAAGVTV

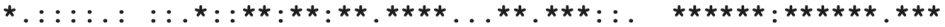

ENAIGGSGNDILVGNSADNILQGGAGNDVLYGGAGADTLYGGAGRDTFVYGSGQDSTVAA ENAIGGSGNDVIVGNAANNVLKGGAGNDVLFGGGGADELWGGAGKDIFVFSAASDSAPGA ENAFGGSGNDLIIGNQVANTIKGGAGNDLIYGGGGADQLWGGTGSDTEVYGASSDSRPGA ENAIGGSGSDLLIGNDVANVLKGGAGNDILYGGLGADQLWGGAGADTFVYGDIEESSAAA ENAIGGSGSDLLIGNDVANVLKGGAGNDILYGGLGADQLWGGAGADTFVYGDIAESSAAA ENAIGGSGSDLLIGNDVANVLKGGAGNDILYGGLGADQLWGGAGADTFVYGDIAESSAAA

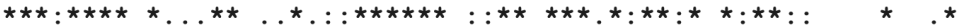

YDWIADFOKGIDKIDLSAFRNEGQLS---FVQDOFTGKGQEVMLOWDAANS ITNLWLHEA SDWIRDFQKGIDKIDLSFFNKEAQSSDF IHFVDHFSGTAGEALISYNASSNVTDLSVNIG ADKIFDFTSGSDKIDLSGITK----GAGVTFVNAFTGHAGDAVLTYASGTNLGTLAVDFS PDTLRDFVSGQDKIDLSGLDAFVNGGLVLQYVDAFAGKAGQAILSYDAASKAGSLAIDFS PDTLRDFVSGQDKIDLSGLDAFVNGGLVLQYVDAFAGQAGQAILSYDAASKAGSLAIDFS PDTLRDFVSGODKIDLSGLDAFVNGGLVLOYVDAFAGKAGOAILSYDAASKAGSLAIDFS

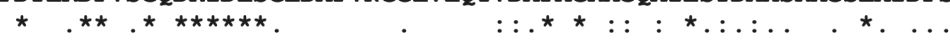

GHSSVDFLVRIVGOAAOSDIIV- (479 aa) GHQAPDFLVKIVGQVDVATDFIV $(487 \mathrm{aa})$ GHGVADFLVTTVGQAAASDIVA- $\left(\begin{array}{ll}477 & \text { aa }\end{array}\right)$ GDAHADFAINLIGQATQADIVV- $(481 \mathrm{aa})$ GDAHADFAINLIGQATQADIVV- $(481 \mathrm{aa})$ GDAHADFAINLIGQATQADIVV- (481 aa)

E.ch.

S.m.

P.f.

P.a.18

P.a. 9

P.a.

E.ch.

S.m.

P.f.

P.a. 18

P.a. 9

P.a.

E.ch.

S.m.

$P . f$.

P.a.18

P.a. 9

P.a.

E.ch

S.m.

P.f.

P.a. 18

P.a. 9

P.a.

E.ch.

S.m.

P.f.

P.a. 18

P.a. 9

P.a.

E.ch.

S.m.

P.f.

P.a. 18

P.a. 9

P.a.

E.ch.

S.m.

P.f.

P.a. 18

P.a. 9

P.a.

E.ch.

S.m.

P.f.

P.a. 18

P.a. 9

P.a.

Figure 7. Alignment of amino acid sequences of alkaline proteases from $P$. aeruginosa strains:

ATCC 27853 (P.a.) (Acc. No AFX88326), PA C124/9 (P.a.9) (AFX88324), and PA 02/18 (P.a.18) (AFX88325), PrtC of D. dadantii (E.c.) (AAA24860), an alkaline metalloprotease of S. marcescens ATCC 13880 (S.m.) (KFD16023), and AprA of P. fluoresencs A506 (P.f.) (AFJ54733). The motif and conserved residues responsible for binding $\mathrm{Zn}$ ions are marked by a black line and boxes, respectively. Amino acids identical in all of the six analysed proteins in individual protein sites are marked with asterisks $(*)$, amino acids identical in five proteins are marked with colons (:), whereas amino acids identical in four of the analysed proteins are marked by dots (.). 
incubation at $60^{\circ} \mathrm{C}$, respectively, but it completely lost the activity after $15 \mathrm{~min}$ incubation at $80^{\circ} \mathrm{C}$. The alkaline protease of $P$. aeruginosa strain $\mathrm{K}$ was completely inactivated upon incubation at $80^{\circ} \mathrm{C}$ for 30 min (Rahman et al., 2006).

Steady-state fluorescence spectroscopy was used to examine changes in the molecular organization of the alkaline protease of $P$. aeruginosa PA18 associated with its heat-induced denaturation and renaturation. As expected, the high temperature affected the enzyme's spatial structure. However, after cooling, the value of fluorescence intensity of the $60^{\circ} \mathrm{C}$ - and $90^{\circ} \mathrm{C}$-pre-treated enzyme was only $20 \%$ lower than the value of fluorescence intensity of the native protein, indicating the high level of recovery of the enzyme's spatial conformation. The fluorescence changes detected at $60^{\circ} \mathrm{C}$ (a shift of the maximum fluorescence from $337 \mathrm{~nm}$ to $340 \mathrm{~nm}$ ) may indicate an increase in the exposure of tryptophan residues to the polar solvent resulting from the thermal protein unfolding (Lakowicz, 1999; Uttam et al., 2011; Zhang et al., 2012; Ghisaidoobe \& Chung, 2014). On the other hand, it cannot be excluded that the observed decrease in fluorescence intensity at this temperature may also result from the effect of temperature on the fluorescence emission intensity. It is known that fluorescence intensity of aromatic amino acids decreases along with an increase in the temperature of the sample (Gally \& Edelman, 1962). The appearance of the band at a longer wavelength, mainly after cooling $(377 \mathrm{~nm})$, can be attributed to protein fluorophore aggregates resulting from the formation of a large macromolecular protein structure (Lakowicz, 1999). It was demonstrated that the RTX-containing domain of $P$. aeruginosa alkaline protease can form polymers (Zhang et al., 2014), a feature that may be involved in the observed changes. The higher level of oligomerization after the $90^{\circ} \mathrm{C}$ pre-treatment in comparison to the pre-treatment at $60^{\circ} \mathrm{C}$, may also contribute to the lower level of activity of the renatured enzyme pre-incubated at $90^{\circ} \mathrm{C}$. In addition, molecular oligomers are known as very effective fluorescence quenchers (Bhattacharya et al., 2011; Hong et al., 2011). Hence, the partial protein oligomerization, in addition to the possible protein unfolding, can explain the lack of total recovery of the alkaline protease fluorescence intensity. A similar effect was reported for recombinant Acinetobacter baylyi diketoreductase. An analysis of thermal-induced unfolding and renaturation of this enzyme indicated that renaturation from $90^{\circ} \mathrm{C}$ and $80^{\circ} \mathrm{C}$ was more complete than that from $70^{\circ} \mathrm{C}$ and $60^{\circ} \mathrm{C}$, with a tendency of better recovery of enzymatic activity from higher unfolding temperatures. The phenomenon was explained by a collective contribution of partial aggregation and structural changes occurring in the protein molecules ( $\mathrm{Lu}$ et al., 2010). In turn, results of a study performed on Escherichia coli $\gamma$-glutamyltranspeptidase, a hetero-dimeric enzyme, suggested that structural features of a large subunit were important for the renaturation process after thermal denaturation (Van Ho et al., 2013). Interestingly, presence of an additional loop composed of 12 residues in the C-terminal segment of the Bacillus subtilis $\gamma$-glutamyltranspeptidase large subunit caused steric perturbations and prevented reconstitution of the active hetero-dimer complex after thermal denaturation (Van Ho et al., 2013).

Analysis of the secondary structure based on infrared absorption spectroscopy (FTIR) confirmed the high renaturation capability of the studied alkaline protease. The results did not show any clear changes in the $\alpha$-helix configuration $\left(1655 \mathrm{~cm}^{-1}\right)$ and extension of the $\beta$-sheet band within amide I. This suggested recovery of the secondary structure of the enzyme subjected to pre-incubation at $60^{\circ} \mathrm{C}$ and $90^{\circ} \mathrm{C}$. However, the slight decrease in $\beta$-sheet band intensity concomitantly with the increase at $1600-1620 \mathrm{~cm}^{-1}$ could suggest partial protein aggregation (Tamm \& Tatulian, 1997). It was demonstrated that a function of temperature is a decrease in predominantly secondary structural element, $\beta$-sheet or $\alpha$-helix, which is replaced by intermolecular $\beta$-sheet structure common in the aggregated state of proteins (Dong et al., 1997; Dong et al., 2000; Kong \& Yu, 2007).

The results indicated an intrinsic ability of the studied alkaline proteases to partially regain spatial conformation after thermal denaturation and subsequent cooling, which allowed partial recovery of activity. After exposure to further denaturing conditions (SDS), the enzymes were even more prone to renaturation, which was clearly evidenced by zymography. Most probably, an important factor in this process was the presence of calcium ions in a zymography buffer, known to induce proper folding and stabilization of a $P$. aeruginosa alkaline protease (Zhang et al., 2012).

The high identity of the nucleotide and amino acid sequence of the studied alkaline proteases with alkaline metalloproteases produced by other $P$. aeruginosa strains suggests that the renaturation capability reported here may be a common feature of $P$. aeruginosa alkaline proteases. As mentioned, Zhang and others (Zhang et al., 2012; Zhang et al., 2014) reported on the role of calcium ions in induction of proper folding and stabilization of the molecular spatial conformation of a $P$. aeruginosa alkaline protease. In single site mutation experiments in which a Val residue located centrally in the interface between the RTX and proteinase domains was replaced by an Asp residue (V280D), they demonstrated that disruption of the domain-domain interface had reduced the protease activity and that proper association between these two domains is important for folding and activity of AP. Furthermore, truncation or disruption (A5D, V9D, F12D) of the $\mathrm{N}$-terminal $\alpha$-helix caused a decrease in the AP stability, suggesting a critical role for interactions between this $\alpha$-helix and RTX domain for native state stability (Zhang et al., 2012). The alkaline protease, as other RTX-containing proteins, is secreted by the Type 1 secretion system ('T1SS). Due to the physical constrains of this system, most probably the protein has to be unfolded during the secretion process and becomes folded at an appropriate concentration of calcium ions once secreted outside the cell. The high renaturation capability of $P$. aeruginosa alkaline protease demonstrated in this paper may additionally facilitate effective folding of the molecule after secretion, thereby contributing to the enzymatic activity. Exploring AP properties that influence its folding provides further insight into understanding the mechanisms of virulence of Pseudomonas and other Gram-negative bacteria that utilize RTX-containing virulence factors. Actually, production of this type of proteins may favour bacteria in the competition with other microorganisms fighting for the same niche inside the body of an infected host, as well as in the external environment.

\section{Acknowledgements}

The authors acknowledge the technical assistance of Monika Koziej. We thank Prof. E.A. Trafny (Department of Microbiology and Epidemiology, Military Institute of Hygiene and Epidemiology in Warsaw, Poland) 
for providing the clinical isolates of $P$. aeruginosa. We are grateful to Dr. R. Voulhoux (Laboratoire d'Ingénierie des Systèmes Macromoléculaires, CNRS UMR7255, Institut de Microbiologie de la Méditerranée, France) for the anti-alkaline protease antibodies.

\section{REFERENCES}

Andrejko M, Mizerska-Dudka M (2012) Effect of Pseudomonas aeruginosa elastase B on level and activity of immune proteins/peptides of Galleria mellonella hemolymph. J Insect Sci 12: 88. https://doi, org/10.1673/031.012.8801

Andrejko M, Zdybicka-Barabas A, Janczarek M, Cytryńska M (2013) Three Pseudomonas aeruginosa strains with different protease profiles. Acta Biochim Pol 60: 83-90

Baumann U, Wu S, Flaherty KM, McKay DB (1993) Three-dimensional structure of the alkaline protease of Pseudomonas aeruginosa: a two-domain protein with a calcium binding parallel beta roll motif. EMBO J 12: 3357-3364. PMCID: PMC413609

Bayoudh A, Gharsallah N, Chamkha M, Dhouib A, Ammar S, Nasri M (2000) Purification and characterization of an alkaline protease from Pseudomonas aeruginosa MN1. J Ind Microbiol Biotechnol 24: 291-295. https://doi.org/10.1038/sj.jim.2900822

Bhattacharya M, Jain M, Mukhopadhyay S (2011) Insights into the mechanism of aggregation and fibril formation from bovine serum albumin. J Phys Chem B 115: 4195-4205. https://doi.org/10.1021/ ip111528c

Blake MS, Johnston KH, Russell-Jones GJ, Gotschlich EC (1984) A rapid, sensitive method for detection of alkaline phosphatase-conjugated anti-antibody on Western blots. Anal Biochem 136: 175-179. https://doi.org/10.1016/0003-2697(84)90320-8

Bradford MM (1976) A rapid and sensitive method for quantitation of microgram quantities of protein utilizing the principle of proteindye binding. Anal Biochem 72: 248. https://doi.org/10.1016/00032697(76)90527-3

Butterworth MB, Zhang L, Heidrich EM, Myerburg MM, Thibodeau PH (2012) Activation of the epithelial sodium channel (ENaC) by the alkaline protease from Pseudomonas aeruginosa. J Biol Chem 287: 32556-32565. https://doi.org/10.1074/jbc.M112.369520

Caballero AR, Moreau JM, Engel LS, Marquart ME, Hill JM, O'Callaghan RJ (2001) Pseudomonas aeruginosa protease IV enzyme assays and comparison to other Pseudomonas proteases. Anal Biochem 290: 330-337. https://doi.org/10.1006/abio.2001.4999

Caine S, Heraud, P, Tobin MJ, McNaughton D, Bernard CC (2012) The application of Fourier transform infrared microspectroscopy for the study of diseased central nervous system tissue. Neuroimage 59: 3624-3640. https://doi.org/10.1016/j.neuroimage.2011.11.033

Chanchal H, Tuhin S, Venkataramanan M (2014) A resonance energy transfer approach for the selective detection of aromatic amino acids. J Mater Chem C 47: 10157-10163. https://doi.org/10.1039/ C4TC01954G

Dong A, Kendrick B, Kreilgard L, Matsuura J, Manning MC, Carpenter JF (1997) Spectroscopic study of secondary structure and thermal denaturation of recombinant human factor XIII in aqueous solution. Arch Biochem Biophys 347: 213-220. https://doi.org/10.1006/ abbi.1997.0349

Dong A, Randolph TW, Carpenter JF (2000) Entrapping intermediates of thermal aggregation in $\alpha$-helical proteins with low concentration of guanidine hydrochloride. J Biol Chem 275: 27689-27693. https:// doi.org/10.1074/jbc.M005374200

Duong F, Lazdunski A, Cami B, Murgier M (1992) Sequence of a cluster of genes controlling synthesis and secretion of alkaline proteinase in Pseudomonas aeruginosa: relationships to other secretory pathways. Gene 121: 47-54. https://doi.org/10.1016/0378-1119(92)90160-Q

Duong F, Lazdunski A, Murgier M (1996) Protein secretion by heterologous bacterial ABC-transporters: the C-terminus secretion signal of the secreted protein confers high recognition specificity. Mol Microbiol 21: 459-470. https://doi.org/10.1111/j.1365-2958.1996.tb02555.x

Feltzer RE, Gray RD, Dean WL, Pierce WM Jr (2000) Alkaline proteinase inhibitor of Pseudomonas aeruginosa. Interaction of native and N-terminally truncated inhibitor proteins with Pseudomonas metalloproteinases. J Biol Chem 275: 21002-21009. https://doi.org/10.1074/ jbc.M00208820

Gally JA, Edelman GM (1962) The effect of temperature on the fluorescence of some aromatic amino acids and proteins. Biochem Biophys Acta 60: 499-509. https://doi.org/10.1016/0006-3002(62)90869-7

Ghisaidoobe ABT, Chung SJ (2014) Intrinsic tryptophan fluorescence in the detection and analysis of proteins: a focus on Förster resonance energy transfer techniques. Int J Mol Sci 15: 22518-22538. https://doi.org/10.3390/ijms151222518

Goormaghtigh E, Gasper R, Bénard A, Goldsztein A, Raussens V (2009) Protein secondary structure content in solution, films and tissues: Redundancy and complementarity of the information content in circular dichroism, transmission and ATR FTIR spectra.
Biochim Biophys Acta 1794: 1332-1343. https://doi.org/10.1016/j. bbapap.2009.06.007

Guyot N, Bergsson G, Butler MW, Greene CM, Weldon S, Kessler E, Levine RL, O’Neill SJ, Taggart CC, McElvaney NG (2010) Functional study of elafin cleaved by Pseudomonas aeruginosa metalloproteinases. Biol Chem 391: 705-716. https://doi.org/10.1515/ BC. 2010.066

Guzzo J, Pages J-M, Duong F, Lazdunski A, Murgier M (1991) Pseudomonas aeruginosa alkaline protease: evidence for secretion genes and study of secretion mechanism. J Bacteriol 173: 5290-5297. PMCID: PMC208238

Hoge R, Pelzer A, Rosenau F, Wilhelm S (2010) Weapons of a pathogen: proteases and their role in virulence of Psendomonas aeruginosa. In Current Research, Technology and Education Topics in Applied Microbiology and Microbial Biotechnology, number 2. Mendez-Vilas A, ed, pp 383-395. Microbiology book series, Formatex Research Center.

Hong YQ, Ghebrehiwet B (1992) Effect of Pseudomonas aeruginosa elastase and alkaline protease on serum complement and isolated components C1q and C3. Clin Immunol Immunopathol 62: 133-138. PMID: 1730152

Hong Y, Lamab YWI, Tang BZ (2011) Aggregation-induced emission. Chem Soc Rev 40: 5361-5388. https://doi.org/10.1039/c1cs15113d

Horvat RT, Parmely MJ (1988) Pseudomonas aeruginosa alkaline protease degrades human gamma interferon and inhibits its bioactivity. Infect Immun 56: 2925-2932. PMCID: PMC259672

Howe TR, Iglewski BH (1984) Isolation and characterization of alkaline protease-deficient mutants of Pseudomonas aeruginosa in vitro and in a mouse eye model. Infect Immun 43: 1058-1063. PMCID: PMC264293

Kong J, Yu S (2007) Fourier transform infrared spectroscopic analysis of protein secondary structures. Acta Biochim Biophys Sin 39: 549559. https://doi.org/10.1111/j.1745-7270.2007.00320.x

Laemmli UK (1970) Cleavage of structural proteins during the assembly of the head of bacteriophage T4. Nature 277: 680-685. https:// doi.org/10.1038/227680a0

Lakowicz JR (1999) in Principles of fluorescence spectroscopy, Kluwer Academic Publishers, New York. https://doi.org/10.1007/978-1-47573061-6

Leidal KG, Munson KL, Johnson MC, Denning GM (2003) Metalloproteases from Pseudomonas aeruginosa degrade human RANTES, MCP-1, and ENA-78. J Interf Cytok Res 23: 307-318. https://doi. org/10.1089/107999003766628151

Lu M, Cao X, Yang X, Zheng H, Liu N, Jiang Y, Lin D, Chen Y (2010) A diketoreductase exhibits unique renaturation profile from thermal-induced protein unfolding. Amino Acids 39: 609-613. $0.1007 / \mathrm{s} 00726-010-0491-9$

Miyatake H, Hata Y, Fujii T, Hamada K, Morihara K, Katsube Y (1995) Crystal structure of the unliganded alkaline protease from Psendomonas aeruginosa IF03O8O and its conformational changes on ligand binding. J Biochem 118: 474-479. PMID: 8690704

Moller M, Denicola A (2002) Protein tryptophan accessibility studied by fluorescence quenching. Bioch Mol Biol Edu 30: 175-178. https:// doi.org/10.1002/bmb.2002.494030030035

Okuda K, Morihara K, Atsumi Y, Takeuchi H, Kawamoto S, Kawasaki H, Suzuki K, Fukushima J (1990) Complete nucleotide sequence of the structural gene for alkaline proteinase from Pseudomonas aeruginosa IFO3455. Infect Immun 58: 4083-4088. PMCID: PMC313780

Parmely M, Gale A, Clabaugh M, Horvat R, Zhou WW (1990) Proteolytic inactivation of cytokines by Pseudomonas aeruginosa. Infect Immun 58: 3009-3014. PMCID: PMC313603

Patil U, Chaudhari A (2009) Purification and characterization of solvent-tolerant, thermostable, alkaline metalloprotease from alkalophilic Pseudomonas aeruginosa MTCC 7926. I Chem Technol Biotechnol 284: 1255-1262

Rahman RNZ, Geok LP, Basri M, Salleh AB (2006) An organic solvent-stable alkaline protease from Pseudomonas aeruginosa strain K: enzyme purification and characterization. Ensyme Microb Tech 39: 1484-1491

Rawlings ND, Barrett AJ, Bateman A (2010) MEROPS: the peptidase database. Nucl Acids Res 38: 227-233. https://doi.org/10.1093/nar/ gkp971

Sambrook J, Fritsch EF, Maniatis T (1989) in Molecular Cloning: A Laboratory Manual, Cold Spring Harbor Laboratory Press, New York.

Sievers F, Wilm A, Dineen D, Gibson TJ, Karplus K, Li W, Lopez R, McWilliam H, Remmert M, Soding J, Thompson JD, Higgins DG (2011) Fast, scalable generation of high-quality protein multiple sequence alignments using Clustal Omega. Mol Syst Biol 7: 539. https://doi.org/10.1038/msb.2011.75

Tamm LK, Tatulian SA (1997) Infrared spectroscopy of proteins and peptides in lipid bilayers. Q Rev Biophys 30: 365-429. PMID: 9634652

Twining SS, Kirschner SE, Mahnke LA, Frank DW (1993) Effects of Pseudomonas aeruginosa elastase, alkaline protease and exotoxin A on corneal proteases and proteins. Invest Ophthalmol Visual Sci 34: 26992712. PMID: 8344792 
Uttam A, Chandrima J, Saptarshi M (2011) Protein unfolding and subsequent refolding: a spectroscopic investigation. Phys Chem Chem Phys 13: 20418-20426. https://doi.org/10.1039/c1cp21759c

Van Ho T, Kamei K, Wada K, Fukuyama K, Suzuki H (2013) Thermal denaturation and renaturation of $\gamma$-glutamyltranspeptidase of Escherichia coli. Biosci Biotechnol Biochem 77: 409-412. https://doi. org/10.1271/bbb.120780
Zhang L, Conway JF, Thibodeau PH (2012) Calcium-induced folding and stabilization of the Pseudomonas aeruginosa alkaline protease. $J$ Biol Chem 287: 4311-22. https://doi.org/10.1074/jbc.M111.310300

Zhang L, Franks J, Stolz DB, Conway JF, Thibodeau PH (2014) Inducible polymerization and two-dimensional assembly of the repeats-in-toxin (RTX) domain from the Pseudomonas aeruginosa alkaline protease. Biochemistry 53: 6452-6462. https://doi.org/10.1021/ bi5007546 